EURASIAN RESEARCH JOURNAL,

ERJ, Vol. 3, No. 2, pp. 33-56, July 2021

https://doi.org/10.53277/2519-2442-2021.2-03

ISSN 2519-2442, KAZAKHSTAN

Research Article

\title{
POWER GAMES ON THE SILK ROUTE: A JOURNEY FROM HISTORICAL TO MODERN ERA
}

\author{
Shoaib KHAN ${ }^{1}$
}

1Centre for Central Eurasian Studies, University of Mumbai, 400032 Mumbai, India; e-mail: shoaibk 92in@

yahoo.com; ORCID: 0000-0002-5558-4854

\begin{abstract}
The real aim of the programme is an extension of Chinese power and influence. As per an analyst, it is a game where China is steadily placing counters across Asia and Europe. In the Western views, it is easy to interpret comments as a strategy of China, with the aim of extending Chinese influence in a series of carefully planned steps. Around $114 \mathrm{BC}$ by the Han dynasty, the trade routes of Central Asia were expanded largely through the missions and explorations of Chinese imperial envoy Zhang Qian. The world's greatest economic construction and development project ever is being undertaken by China. In the economic map of the world the New Silk Road project is a revolutionary change. The geopolitical conflicts over the project could lead to a new cold war between East and West for dominance in Eurasia as it is becoming clearer every day.
\end{abstract}

Key Words: Silk Road, Central Asia, China, Russia, US, Asia, Europe, India. 


\section{INTRODUCTION}

The term Belt and Road initiative was used to the Silk Road Economic Belt and the 21st Century Maritime Silk Road. The network connecting the continents of Asia, Europe, and Africa, and passing through more than 65 countries and regions with a population of about 4.4 billion and a third of the global economy. It brings out the picture of how China wants to further connect itself to the global economy and strengthen its influence in the region. The program has been a fresh impetus to China and the rest of the world to promote regional cooperation and presented numerous opportunities for foreign companies to be involved.

The ancient Silk Routes, explains what the BRI entails and China's motivation for driving such a program. More importantly, explores where the real opportunities lie for foreign companies which are looking to get involved. Clear sight is also given as for those interested parties can successfully evaluate the potential of these BRI projects and prepare themselves to face the specific challenges (Wijeratne et al., 2017).

Centuries back, the Silk Road brought caravans of silk and spices, Arabian horses, and precious stones from the East to a Roman Empire eager for exotic luxuries. Today, a new network of Silk Road is forming between China and Europe, but the products are different. The Chinese Belt and Road Initiative promises investments in technology, trade deals, and infrastructure. There are some of the areas where the BRI is giving China influence within the EU, and its potential consequences.

The BRI is about more than trade. The real aim of the program is an extension of Chinese power and influence. As per an analyst, it is a game where China is steadily placing counters across Asia and Europe. In the Western views, it is easy to interpret comments as a strategy of China, with the aim of extending Chinese influence in a series of carefully planned steps. Beyond overstating the foresight of Chinese strategy, such an approach also ignores the role Western disorder has played in allowing China to extend its influence (Warren, 2017).

The program consists of 'One Belt, One Road', 'The Silk Road Economic Belt,' which is the land route linking Central Asia, Russia, and Europe. 'The 21st Century Maritime Silk Road,' the name for the sea route and goes through the Western Pacific and the Indian Ocean. The success of the New Silk Road could be the largest economic development scheme on the face of the earth. The New Silk Road program will be a big win for China (Wang, 2016).

The modern route has been called the Marshall Plan of China by Western commentators. There are several similarities with the $\$ 120$ bn post-WW II program that sought to rebuild Europe through infrastructure and heavy industry as the basis for growth. To rebuild and stabilize Europe was through the US Marshall Plan in the context of the imminent Cold War, the New Silk Road strategy is interesting since it crosses continents. There have been questions raised as to whether it is more akin to the railways that the British Empire built across the colonies (Greater Pacific, 2015). 


\section{THE HISTORICAL ROUTE}

It was from the trade of Chinese silk carried along the route that the name Silk Road was derived, during the Han dynasty (207 BC - 220 CE) (Turchin et al. 2006). In the development of the civilizations of China, a significant factor was the trade on the Silk Road, South Asia, Persia, Europe, the Horn of Africa, and Arabia, opening long-distance, political and economic relations between the civilizations (Bentley, 1993: 32). Around 114 BC by the Han dynasty, largely through the missions and explorations of Chinese imperial envoy, Zhang Qian, the trade routes of the Central Asian sections were expanded (Boulnois, 2005: $66)$.

In practice, the pre-dates of the Han Dynasty witnessed the Silk Road history, however, as the Persian Royal Road, established in 500-330 BC during the Achaemenid Empire served the Silk Road as one of the main arteries. In north Persia from Susa which is modern-day Iran the Persian Royal Road ran to the Mediterranean Sea in Asia Minor modern-day Turkey and featured postal stations along the route to quickly deliver messages throughout the empire where fresh horses were ready for envoys. In time the Persians expanded the Royal Road through smaller side roads and maintained it carefully. In South Asia, these paths crossed down across Mesopotamia, and over into Egypt. The city of Alexandria was established by Alexander the Great in 339 BC, in the Fergana Valley of Neb modern Tajikistan, after he conquered Persia. Alexander moved on and left behind his wounded soldiers in the city.

The intermarriages which took place between these Macedonian warriors and the local populace creating the Greco-Bactrian culture which flourished under the Seleucid Empire following Alexander's death. The Greco-Bactrians under King Euthudemus I (260-195 BC) had extended their holdings. The Greeks extended their empire as far as the Seres the name for China among the Greeks and Romans according to Greek historian Strabo (63 to $24 \mathrm{BC}$ ), meaning the land where silk came from (Mark, 2014).

Crisscrossed with communication routes and paths of trade throughout Eurasian history, which gradually linked up to form what is known today as the Silk Road; routes across both sea and land, along which silk and many other goods were exchanged from across the world. The East linking West by sea, the maritime route which was an important part of this network and was used for the trade of spices in particular, thus came to be known as the Spice Routes. More than just merchandise and precious commodities as carried by these vast networks.

However, the constant movement and mixing of populations also brought about the transmission of knowledge, ideas, cultures, and beliefs, which on the history and civilizations of the Eurasian people had a profound impact. Along the Silk Road the travelers were also attracted by the intellectual and cultural exchange besides trade that was taking place in cities, many cultures and learning hubs were developed out of it. In the societies along the lengths of these routes, arts, crafts, technologies besides literature and science were shared, in this way, languages, religions, and cultures developed and influenced each other.

Across Central Asia the earliest catalysts for the trade routes were the silk trade, 
it was only one of a wide range of products such as textiles, spices, grains, vegetables and fruits, animals woodworks, tools, hides, religious objects, metal works, artworks, precious stones and much more were traded between east and west. Bringing cultures and people in contact with each other has been the role and lasting legacy of the Silk Road and facilitating exchange between them. Across Central Asia, the travelers who carried their cultural knowledge besides spreading features of irrigation systems also absorbed that of the societies in which they found themselves (UNESCO, 2021a).

Unlike China and other countries with a settled way of life, Mongolia along with the regions of Central Asia constituted a distinctively original nomadic world inhabited by aboriginal tribes and clans. Goods reached Mongolia through trade with China, Central Asia, Khotan, and Afghanistan. The country's cultural links extended through Sogdiana to India and across Kazakhstan as far as the Black Sea and Eastern Europe. More powerful tribal unions arose in Inner Asia during the era of 7th to 3rd century B.C.- the Hsiung-nu in the Ordos and Central Mongolia, the Tung Hu in Mongolia's eastern part as well as in the Manchurian western region and the Yüeh-Chih in Gansu and the lands between Dzungaria and Ordos. The Tangut-Tibetan tribes to the south led a nomadic way of life in the vicinity of Koko Nor (Qinghai). The world of nomads in Central Asia was increasingly becoming a military and political power (Okladnikov, 1955).

During Mao-tun after 209 B.C., the Hsiung-nu state rapidly became a powerful nomadic empire. The headquarters of the Hsiung-nu shan-yü was located in the southeast spurs of the Khangay mountains, in a region where Karakorum and the Turkic and Mongol people were settled, other political centers later to came into being. The nephritic seal whose keeper was the leader of Hsiung-nu. The other attributes of sovereignty marked the beginning of a distinctive nomadic power. The Hsiung-nu state system, the rise of which with a capital for the shanyü, a seal, flag, border guards (Bai, 1980: 116; Konovalov, 1976:3).

The caravan trade link after control of a key section of the Silk Route between China and the West, the Hsiung-nu reaped great profits from its international trade. To maintain control of these routes they fought hard and successfully vied with China for the hegemony of Central Asia. The Hsiung-nu and Hsienpi whose distinctive culture together constituted the first important stage in the formation of the nomadic civilization of Central Asia, playing an important role between East and West and linking China and Central Asia, while, at the same time, remaining distinctive with a very significant contribution to world culture (Ishjamts, 2021).

During the early Common Era among the important factors in the development of the Silk Road rapidly was the establishment and growth of the Kushan Empire, which had on the political and economic stability of much of Central Asia a profound effect. Nomadic tribes from the steppes of the Tienshan and Altai mountains whose descendants were pushed westwards by rival groups and who settled in the region of ancient Bactria in the second century BC, the Kushans' territorial expansion brought under their control a large area stretching from modern Uzbekistan in the north to the Indian Ganges Valley in the south. The international trade encouraged by the Han Dynasty in China as well as the Roman Empire, the Kushans' trade-based economy ensured a steady flow of goods, 
people, and attendant cultures throughout the region (Mehendale, 1996).

In ancient times as well as subsequent periods, the Turkic has always been regarded as an inevitable necessity. A commemoration of Iran's several thousand years' history of road construction is caravansaries. Humans long back could not care for the road that was hard, unsafe, and uneven. In the Turkic runic texts of the 8th century, the Silk Road's object-value world was reflected and, in the Turkic speaking poems of urban culture during the flourishing Islamic classics and also found stories of the North Caucasus, Middle and Central Asia and South Siberia, in the lyric and epic heritage of nomadic Nogai and Kazakh zhyrau and akyns of the 15-18th centuries.

During the period of Islamic flourishing creative role of outstanding figures of the Turkic culture is revealed on the Great Silk Road. Cultural information of the intellectual and spiritual and moral environment of the Silk Road runs like a golden thread in Turkic history (Zhumabayeva et al. 2018). A working example of the co-construction and co-creation is being provided by the ancient Silk Road between China and the traders of the Old Middle East of a form of capitalism with a new set of norms of exchange, trade policy, monetary exchange, and, of course, very early forms of capital accumulation and formation was an instrument of financial culture. The most sustained and earliest of merchant capitalism as well as a working example of a theory of trade that comprises three layers based on the movements and the exchange of goods, services, and knowledge (Peters, 2019).

\section{CENTRAL ASIA ON THE SILK ROUTE}

In the region with various unfolding the current situation, new Silk Road initiatives not only resembles the historical prerequisites but looks even more promising. In laying the foundation for regional cooperation new Silk Road are instrumental, creating political flexibility, improving economic growth, offering trade diversifications, investing in transportation, and in mining and energy sectors. A historically unprecedented chance for the Central Asian republics is being represented by these factors to become important players in the world economy. On the path of the ancient Silk Road for countries located, particularly the landlocked Central Asian states, international trade is the only option to sustain economic growth and development (Fedorenko, 2013).

Several initiatives have embarked since the disintegration of the Soviet Union, separately or together, on the momentous task of rebuilding trade and transportation arteries across Central Asia and the Caucasus. The heart of Asia can become a land corridor connecting Europe to Asia through reconnecting the neighbors and historic trading partners to the landlocked new states of the region. The EU's TRACECA project from where it ranges to China's Silk Road Economic Belt. The necessity of developing soft infrastructure besides the trade and transport geopolitics, which are bound to become important both to Central Asia and Europe but which, to date, have been relatively overlooked (Starr et al., 2015).

Beijing expects to synchronize its individual economic development goals with the larger Silk Road vision since economic ties between China and Central Asian 
states are stronger than political discourses prevailing in the region. In Central Asia regimes tend to prioritize their security and shape foreign policies of their countries following their perceptions and home-generated threats. In reality, the Central Asians are still unwilling to be dependent upon any new big brother, while the commitment to regional integration initiatives may be demonstrated by the Central Asian elites.

The willingness of the Chinese leadership to advance its vision of regional integration is demonstrated in the initiatives of the Maritime Silk Road and the Silk Road Economic Belt, which will have significant ramifications in particular for Central Asia. In the context of Central Asia, the Silk Road has long been used by Beijing. This discourse emerged as an official Chinese policy only recently through the Chinese vision of the Silk Road Economic Belt in Kazakhstan as announced by the Chinese President Xi Jinping in 2013. The promotion of its economic agenda in Central Asia which is the Chinese intentions has been underpinned by a series of visits by Xi Jinping to each Central Asian state, and into the region's infrastructure, the investment of $\$ 40$ billion is being restated by him. The determination of China to expand its influence in Asia was further confirmed by the unveiling of the Chinese-backed $\$ 50$ billion Asian Infrastructure Investment Bank (Jochec and Kyzy, 2015).

In Roman times when the Silk Road began, the area that is now Uzbekistan has been an important transit route for trade and itself an active trader. Through the eighteenth and nineteenth centuries, there was a rapid growth of Russian trade in the region, so much so that Russia thought it necessary to secure the region by occupying Tashkent in 1865. Peter Hopkirk's classic the Great Game described, was about trade or the prospects for trade. Uzbekistan in Greater Central Asia was and is the land bridge between many of the world's great cultures and trading partners such as Russia to the north, China to the east, Iran and Europe to the west, and India to the South.

An important bridge for transport from south to north and from east to west as Uzbekistan is, just as it was in the days of the Silk Road. The Ferghana Valley carved out of the Central Asian borders, somewhere in the mid-1920s for example it impeded the flow of transport routes, roads, rail, rivers, ignoring national boundaries. Uzbekistan is also the most populous of the Central Asian states, making it a potentially important internal market for the region (Reiser and DeTray, 2007).

In 1992 the visit of the then-Foreign Minister of China Qian Qichen to Uzbekistan was a turning point. Karimov had in mind the aims which were related less to connecting Chinese markets with European consumers and more to the developmental agenda of Uzbekistan. Russian networks the over-reliance of which had been on Uzbek infrastructure for both the export of Uzbek goods and resources and transportation services.

The Chinese cooperation represented a de-colonization drive towards China-focused infrastructure to compensate for over-dependency on Russia and offer more trade routes for Uzbekistan. China with its developmental agenda as viewed by Uzbekistan in which the government plays a significant role in the otherwise liberalized market economy (Dadabaev and Djalilova 2020). 
The strategic interests of Uzbekistan to integrate with CA countries have many potential economic developments for the country, and consequently, it is possible for China to emphasize its economic influence in exporting products and importing energy from Uzbekistan. Bilateral economic agreements have been signed between China and Uzbekistan since 2002 that increased investments in machinery, oil, and building infrastructures. According to the Ministry of Commerce, China is Uzbekistan's second-largest trade partner and investor.

Today, China, via OBOR initiatives, is integrated with Uzbekistan's plan for economic development. It is planned to invest in railroads, roads, tunnels, and other transportation projects. In this context, China and Uzbekistan foresee mutual benefits arising from strong future economic developments. The project's value for Uzbekistan in 2016 reached $\$ 6.83$ million with an accumulative turnover of $\$ 4.75$ billion. Today in Uzbekistan, the number of Chinese-based capital enterprises is more than 600 , where the majority of joint projects have been implemented. Apart from industrial-related investments, the technological partnership began to produce the main 17 investment operations as well (Khamidova, 2017).

The history of the Silk Road in the III-II century BCE the period from which the territory of the modern Republic of Kazakhstan was one of the first regions, which confronted the influence of the first commercial and cultural contacts with civilizations remote from the Central Asian region. Linkages between Kazakhstan and the Silk Road historically, require serious complex scientific research, which will be far too long for this contribution. A unique instrument the Silk Road corridor, which works as the transmission of economic, linguistic, cultural, religious, military, and political values and innovations between different civilizations across the Eurasian continent.

Migrations of nomadic communities besides armed conquests on the territory of Eurasia have a comparable short-term influence on these types of inter-civilization exchanges until the modern era of globalization (Voyakin and Pachkalov, 2010). On the territory of modern Kazakhstan, the human societies which existed are difficult to discuss the constant and persistent importance of the contacts along the Silk Road for the development of the local economy and their international contacts. Rise and demise of civilizations and states, military conflicts and expansions, population movements, natural disasters and climate changes from antiquity to the end of the modern period, the role of the Silk Road were never marginal for the Central Asian region, which had no access to maritime commerce due to its geographical location in the center of Eurasia (Baipakov and Voyakin, 2010).

Kazakhstan was the first country among Central Asian states that proposed a new Silk Road initiative in 2007 to Russia and China under the umbrella of the Western Europe-Western China project (WE-WC) (Bitabarova, 2018). The transport corridor aimed to reduce the shipping time for transportation of goods from China to Europe and back from 30-50 days by sea and 12-15 days by railway to 7-10 days along the highway (Europe-China.kz, 2020). Kazakhstan, Russia, and China the participating countries for which the implementation of the WC-WE project was expected to bring additional economic benefits through improved infrastructure from the participation of linking cities and regions in international goods exchanges. 
In the case of Kazakhstan, in addition to the strengthening of the country's transit potential, the WE-WC transport corridor aimed to boost regional development and benefit at least $30 \%$ of its population, including 5.5 million people lives in 200 settlements along the corridor. Kazakhstan initiated the WE-WC projects before the Chinese Belt and Road Initiative (BRI), which serves as an insightful case to study the impact of foreign investment in the Silk Road transport corridor on the sustainability of regional development in Central Asia. The new vision of the Silk Road as declared by China of its vision in 2013, named the Belt and Road Initiative (BRI), was, to a certain extent, stimulated by the established institutional setting of the Eurasian Economic Union and the benefits expected from the implementation of the WE-WC project (Czerewacz-Filipowicz, 2019).

The project was financed by many international banks, BRI had a single investor. China allocated $\$ 1$ trillion to the development of infrastructure with a special focus on Central Asian countries, whose territories can serve as land bridges for connecting China with Europe (Lobyrev et al., 2018). Kazakhstan's strategic position on the New Silk Road empowers it as a logistics linchpin between China and Russia, East Asia, and Europe. Political stability in Central Asia on which the Kazakh position is being cemented, its relatively higher per capita income, sophisticated service economy, highly developed energy sector, and through the southern Kazakh border from where the old Silk Road ran along the old Steppe Road through its very heart.

To promote the establishment of regional headquarter hubs air transportation, logistics, and financial are gathered. Developing facilities which encompass Road, Rail, Runway, and River. This outcome is part of Kazakhstan's destiny, sophisticated planning and development are necessary, and this will require integration and coordination between Khorgos, Almaty, Astana, and ongoing Chinese investment (Wang, 2017).

The so-called Gate to Central Asia, the ancient Turkmen city of Merv was especially important in terms of trade and politics in the 9th - 10th centuries. The travelers further moved to Chardzhou in Turkmenistan and further to Bukhara and then to Samarkand (Selmier II, 2019). The Parthian tribes of horsemen arrived to establish their capital in Turkmenistan at Nisa in 3rd B.C. The Parthians were a power that rivaled Rome and from Nisa, they had control over the Silk Road and oasis settlements and trading centers like the harsh desert cities of Merv and Serakhs. Throughout the region, the country was famous for producing the skilled and fierce nomadic tribesmen who rode out on raids to seize the riches of the passing caravans. On the Silk Road, many important cities are in Turkmenistan (Advantour.com, 2021a).

Turkmenistan SSR formerly, surrounded by Iran, Afghanistan, Uzbekistan, Kazakhstan and the Caspian Sea are its shared borders. The Persian province of Khurasan of which Turkmenistan has been its part for centuries; in medieval times Merv was one of the great cities of the Muslim world and an important stop on the Silk Road. In between 1865 and 1885 it was conquered by Russia. Turkmenistan became a Soviet republic in 1924. After the disintegration of the Soviet Union, it had its independence.

The country is located on the transportation of historical corridor has long been connecting the East and West, Turkmen tribes sometimes played the role of 
spoilers and isolated themselves within the region. The society of Turkmenistan is still based on the relations between tribes and clans, and it does not have a firm identity among the population as a state. One of the most fundamental challenges for the leader of Turkmenistan as it became independent was the establishment of identity to foster the state-building (Cis-legislation.com, 2019).

Opening itself to the world of Turkmenistan with the development of large-scale infrastructure projects included transnational energy projects and multimodal regional transport corridors. Being part of Central Asia, surrounded by the Middle East, South Asia, and the Caucasus, Turkmenistan can become a major hub when further reforms will be carried out in collaboration with regional countries. Cooperation at the regional level is required to achieve this goal. Turkmenistan President Gurbanguly Berdimuhamedov met with China's President Xi Jinping in June 2016 in Tashkent and had discussed further cooperation with the Belt and Road Initiative.

Turkmenistan's geographical location makes it one of the most important connection members and supporters of the International North-South railway transportation corridor which provides a railway connection between Russia-Kazakhstan-Turkmenistan-Iran. The China-Azerbaijan-Europe corridor via Turkmenbashi seaport of Turkmenistan on the shore of the Caspian Sea. Alongside the Persian Gulf, Chinese freights can also easily be accessed to Europe through this corridor (Yildiz, 2007).

The three major routes of the Silk Road ran through the present-day territory of Tajikistan. In contemporary Persian, Greek, Chinese, and Arabic sources there are mentions of these routes which highlighted Tajik contributions to the commerce and culture of the time, especially between the 5th and 12th centuries. The North route between Samarkand and Kashgar was the first route; the second one was the Karategin route between Termez and Kashgar and the third one was the Pamir route linking Balkh and Tashkurgan. Tajikistan besides the sites of its Silk Road has the Pamir Mountain range, sometimes called 'The Roof of the World'. It is from here that the spread of three great ranges of Central Asia -the Hindu Kush, the Karakorams, and the Tien Shan begin (Choganov, 2021).

The Venetian explorer Marco Polo passed this way when it was part of the ancient Silk Road, a vast network of trade routes running from China to the Mediterranean, spreading not only silk and other goods, but also arts, technologies, ideas, and belief systems across the globe (UNESCO, 2021b). Achaemenid Empire of which Tajikistan was a part subdued by Alexander the Great in the fourth century B.C. and then became part of the Greco-Bactrian kingdom. Part of Sogdiana the northern part of what is now Tajikistan. China to the west and south on which as intermediaries the Sogdians on the Silk Route imparted religions such as Buddhism, Nestorian Christianity, Zoroastrianism, and Manichaeism, their script and other knowledgeable materials were found to settlements along the routes. The region was conquered by Arabs in earnest in the early eighth century.

The most important state in Central Asia after the Muslim conquest was the Persian-speaking Samanid principality (875-999) (Wilder, 2020). The crossroads since ancient times between the East and the West made Khujand one of the major economic and cultural centers of Central Asia, the major center on the Silk Road. The products from silk, jewelry made by craftsmen of Khujand 
were known not only in the East but also in the Western world (Advantour.com, 2021b). The country can be of great interest to China for having renewable hydropower resources in a vast quantity. Central Asia to which the Chinese expect to become a developed transport corridor for them.

Tajikistan to finally get out of the transport impasse for which it has been for two decades. There must be appropriate specific projects to transform this interest into a reality. It should be stressed that Tajikistan has such projects, and it has proposed China to take part in their implementation many times (Ghani, 2021).

In China's Belt and Road Initiative, Tajikistan is a crucial piece. The United Nations-backed Beijing claims that BRI investments in trade-creating infrastructure projects will raise living standards for participating countries, to date, its ventures in Tajikistan suggest otherwise. The BRI is a mutually advantageous opportunity, while China bolsters its access to foreign markets and diversifies supply chains, Tajikistan receives much-needed development infrastructure to facilitate economic development (Reynolds, 2018).

The caravans in ancient times turned their routes time and again, except for those basic directions from the East to the West and from the West to the East. Due to its nearness to the Tien-Shan and Pamir mountains, the route remained the same passing through Kyrgyzstan. Through the territory of modern Kyrgyzstan, the present-day Silk Road passed in the middle ages - Pamir-Alay, Fergana, and Chuya. Along with the inflow of the Kyzyl-Suu to Alay through Samarkand, the first branch from Termez and then led to Kashgar.

To the city of Osh, the Fergana line went through Khujand from Samarkand. When caravans went further to Kashgar across the Torugart Pass the intermediate trade point was Osh. It was from Zamin Rabat to Tashkent, Ispedzhab, Taraz, Nuzket, Kara-Balta, and Balasagyn also Buran that the third branch passed through it. The Issyk-Kul area was reached by the caravans which traveled further to China across the San-Tash range.

The emergence and growth of rich cities led by the presence of caravan routes, trade and craftsmen's villages, caravanserais Dzhul, Suyab, Novokent, Balasagyn, Boroskohon, Tash Rabat, Osh, and Uzgen. Medieval Kyrgyzstan became one of the cultural centers of ancient Turkic people (Advantour.com, 2021c). The route provided an impetus for more joint efforts between China and Kyrgyzstan which is already strong due to their shared land border. Implemented in Kyrgyzstan currently the BRI-related projects in road and energy infrastructure rehabilitation, urban development, mining, manufacturing, and other sectors of the economy (Mogilevskii, 2019).

The region is offered important routes by Kyrgyzstan and provides a wholesale market for affordable Chinese consumer goods. Since Kyrgyzstan has been the only country in Central Asia to share World Trade Organization membership with China for several years, the two countries' low trade protection barriers have made Kyrgyzstan turn into a major trade to the rest of the region. However, political turmoil and weak economic development make Kyrgyzstan vulnerable to China's commercial and economic expansion (Peyrouse, 2012).

A local component of BRI in Central Asia, it brands itself as an all-inclusive project that would reach even the outskirts of Kyrgyzstan, the Kyrgyz market 
is flooded with Chinese consumer goods (Guluzian, 2017). Up to 80 percent of finished goods in Kyrgyz markets arrive from China before being re-exported to the rest of Central Asia, Russia, and elsewhere (Cooley, 2014: 86). This trend exists in the giant Dordoy container market in Bishkek's northern suburb, the region's largest hub for wholesale and retail trade transactions (Alf, 2016). While Bishkek is heavily dependent on workers' remittances and trades with Moscow, money provided under China's Silk Road Economic Belt initiative offers an alternative way to boost economic development and provide employment, as demonstrated by the construction of new hydropower projects in Kyrgyzstan (Frolovskiy, 2016).

Central Asia is Afghanistan's extended neighborhood not only based on geographical continuity but also in terms of religious, cultural, spiritual, and ethnic affinities. Afghanistan's Tajik, Hazara, and Uzbek population and its Sunni Islamic tradition have established closer links with the people of Central Asian republics. Considering security problems transcending the Central and South Asian borders today, Afghanistan has also shared common strategic interests with its neighbors. Furthermore, in recent years, the initiatives to revitalize new Silk Road projects have emphasized the increasing importance of regional economic cooperation. The debates over Greater Central Asia have attracted a great deal of attraction once again (Arzu, 2016).

\section{INTERESTS AND GAMES OF BIG AND REGIONAL ACTORS}

The United States developed the New Silk Road Initiative in 2011 to fill the void out of the military presence departure as a means for Afghanistan to integrate further into the region by reconstructing significant infrastructure and resuming traditional trading route links which the decades of conflict have broken (Weitz, 2015). In the region along with the western allies, the US hopes to bolster peace and stability through supporting trade links and helping open new markets connecting Afghanistan to Central Asia, Pakistan, India, and beyond. While the majority of experts are skeptical of the prospects of the US-led New Silk Road Initiative, several projects have already found monetary and strategic backing (Standish, 2015).

Washington aims to bridge Central Asian countries to Afghanistan through a regional policy compatible with the vision mentioned above especially after the withdrawal of foreign military forces from this war-weary country. American New Silk Road project which was first envisioned in 2011 is to boost trade and connectivity and to create renewed economic ties between Afghanistan and Central Asia. This policy was updated during the visit of the then U.S. Secretary of State, John Kerry to Central Asian countries. In this visit, a new format for dialogue, the $\mathrm{C} 5+1$ that allowed the Secretary and ministers to discuss regional and global issues (U.S. Embassy in Tajikistan, 2015).

However, the U.S.-led projects are generally criticized as they seem to bolster Afghanistan, rather than Central Asia itself. Another Silk Road project was announced by President Xi during the official state visits to Kazakhstan and Indonesia in late 2013. Chinese One Belt, One Road economic plan for Central Asia, a massive infrastructure and trade strategy of railways, roads, and pipelines to 
bind several countries in Asia, Europe, and Africa has funneled over $\$ 50$ billion into the region since 2013

Chinese new infrastructure projects have two ways. The first one is a new Silk Road Economic Belt to extend westward from Horgos into Central Asia and beyond. The second consists of a 21st century Maritime Silk Road connecting China to Southeast Asia, the South Asian Subcontinent, the Middle East, Western Africa, and ultimately Europe (Chou and Bryant, 2015).

In the backwater of global political and economic attention for which Central Asia has been for centuries, tales of the Great Games and Silk Road are notwithstanding. In recent years there has been a rise in outside interest in the region, Central Asia's energy resources are of great importance to its neighbors in Europe and Asia. Russia considers Central Asia as part of its historical, economic, and regional interests and draws heavily on Central Asian migrants, China wants a peaceful backyard from where it can draw cheap energy.

The common Turkic heritage of the region attracted Turkey. The Tajik people share common cultural and language ties with Iran. Central Asia's Muslim tradition connects it with the Middle East and other Muslim countries. And now NATO countries rely on Central Asia for transit of their non-lethal military supplies in their engagement in Afghanistan (Linn, 2012).

The orientation of the Central Asian economies was mostly towards Moscow during the Soviet era. To gain access to markets they can now look towards China, besides South Asia, Europe, and the Middle East, while maintaining strong links with Russia. A large share of the global economy is being made up by the neighbors of Central Asia and count among them the most dynamic economies of the world. To consider Central Asian countries as handicapped by their landlocked position which previously might have been accurate, it is now more appropriate to think of them as facing great opportunities for being land-linked to the world's great and dynamic economies.

Access to their neighbors' goods, energy, capital, and labor markets will benefit them, besides the potential transit trade which will develop across Central Asia in its linkages from West to East, North to South, and from Europe to Asia. The successful, small, land-locked countries of Europe to which Central Asia is being compared is a way to view this potential process Austria, Liechtenstein, Luxembourg, Switzerland, Czech Republic, Hungary, and Slovakia. These countries have long taken great advantage of the historic economic integration process of Europe and have been able to create great prosperity for their citizens instead of being suffered in the landlocked position.

The Silk Road varies from a different point of view in the beginning and ending points. The Silk Road in the broadest sense stretches from Japan to Britain. As a part of East Asian regional trade routes which considers both Japan and China, and Britain as a part of European regional trade routes, it can be said that Silk Road is a network of roads between Xian in the East, and Crimea and Anatolia in the West (Umesao and Toh, 1992).

Erdogan has taken a more aggressive posture after the election victory, to realize his dream of reviving the Ottoman Empire both domestically by pushing for a Presidential System and internationally by deploying Turkish troops abroad. 
Turkey would also set up a permanent military base in Iraq announced by Hurriyet Daily when Ankara sent around 200 soldiers accompanied by 20-25 tanks to Bashiqa near Mosul which is oil-rich, in the same period a deal was reached with Kurdistan Regional Government (KRG). Turkey moved its troops after protests from Iraq at the UN, while it is not yet clear where other troops would move to (Hurriyetdailynews.com, 2015).

China and Turkey have divergent interests in Syria, Beijing prefers a secular regime that would not export Wahabi/Salafi extremisms to China's Muslim population. Whether Erdogan would make compromises with Eurasian states that are receiving blowback from his current Syrian policy of supporting militants opposed to Assad is key to eventual Eurasian integration via the Silk Road (Arpacik and Safak, 2015).

In the new land Silk Road, if India participates, it will pass from the regions of Aksai Chin in China and Pakistan administered Kashmir, both of which are considered by New Delhi as a foreign occupation of Indian territories. To reap economic benefits by participating in projects from a region that is considered disputed, India is a bit counterintuitive because accepting any economic gains is a denunciation of India's claim. The general populace will not take it well.

China proposes to include India in the Silk Road economic belt by extending the new Lhasa- Kathmandu railway line to Patna and probably further to Kolkatta. Similar are the Indian security concerns and the presence of Kolkatta seaports along with other cities obviates the need for participation in such a project which involves many difficulties logistically for instance a dedicated customs department to be created at the Nepal border. The new Maritime Silk Road if it turns out to be more than a marketing campaign Indian participation is doubtful along similar lines. India considers the development of seaports by China for the maritime Silk Road as a containment strategy to neutralize India

To improve its connectivity in the neighborhood India has its initiatives, the $\$ 40$ billion Silk Road fund could assist India's own infrastructural development. Besides the Silk Road incorporates Bangladesh, China, India, and Myanmar (BCIM) and the Pakistan-China Economic Corridor through the Pakistan Administered Kashmir. To connect China's ports with ports in Vietnam, Malaysia, Indonesia, India, Sri Lanka, Greece, and Kenya are the aims of the Maritime Silk Route. India is participating in the BCIM due to its strategic concerns over Chinese domination in the Indian Ocean. Annually Rs:20,000/- crore has been allocated by the Indian government for the infrastructural development in the country and any additional funding could speed up the process (The Economic Times, 2015).

The route itself is not a formal policy nor a clearly defined geopolitical strategy, rather it is an evolving narrative. The EU-China bilateral relations have partly shaped these perceptions as well as European plans towards Asian connectivity. These views have been affected by the strategic approach of Europe towards Eurasia as well as national prerogatives. A more coordinated approach has been evolved by the European since 2017.

Chinese initiatives of increasing investments in cross-border infrastructure were welcomed by the European Union with the view that it should adhere to market 
rules, international financial and environmental norms. More focus of China has been on Central and Eastern Europe (CEE) through this BRI and the Mediterranean region. Concerns have been led by some projects over the possibility of diluting European political unity or investment rules. Among European countries, there is much room for political coordination, notably by being more proactive in promoting, for example, the infrastructure projects which the EU has already financed in CEE and by generally seeking to promote the EU-Asia connectivity plans (Lisbonne de Vergeron, 2018).

A more stable and secure Eurasia a vision of the EU is being delineated. The EU's strategic role in Eurasia needs to be incorporated, its views on Asian security architecture and its vision for governance vis-à-vis other important stakeholders, including not only the US and China, but also Russia and India, middle powers, and local actors. Policy suggestions need to be included for this vision for a more unified and strategic EU approach to security interests in Central Asia and South Asia. This vision could then act as the guideline for all EU endeavors in, and assessment of other Eurasian security and connectivity proposals, including the Belt (Ghiyasi and Zhou, 2017).

The United States announced its own New Silk Road Initiative in 2011 that aimed to connect Central Asia to Pakistan and India via Afghanistan. To support the integration of Afghanistan into the broader region was the ultimate goal and to provide a boost to the Afghan economy. The NSRI shares a focus on energy and transportation infrastructure with China's New Silk Road Economic Belt. In both China and the broader region, it was received with skepticism. The project is being dismissed by the Chinese as an attempt to maintain America's influence in the region as the U.S. draws down forces in Afghanistan. Whether Washington is willing to commit the political and economic capital required to support a major effort is being questioned by Beijing. The fact that several major initiatives appear to be stalled, including the perennial Turkmenistan-Afghanistan-Pakistan-India Pipeline (TAPI).

Construction of its portion of the pipeline would begin in December 2015 as announced by Turkmenistan. There is a doubt that Washington's interests in engagement are only when it wants to influence China, a common refrain is that to coordinate. Any resources freed in Afghanistan that could be redirected toward containing China is of concern. In the region aligned interests are being shared by China and the United States. The preliminary work done by the U.S. in its efforts to connect Afghanistan to its neighbors, as well as the institutional knowledge gained, may prove valuable to China's planning (Zimmerman, 2015).

Although mainly in Afghanistan, the New Silk Road strategy, it is for the United States itself that has strategic significance. A safe, stable, and prosperous Afghanistan needs security, and stability of the region is the New Silk Road starting point. However, the focus is not limited to this point. The United States government on the New Silk Road was conceived early in 2009, have been prototype as per the findings of Ambon Research team, 2009 October 6th, the United States Department of State for Political Affairs William Burns to the American Chamber of Commerce published a speech, the theme is the Silk Road trade and Investment and the new path of the Central Asia economic ties with the US, he in his speech referred to the establishment and strengthening economic ties with Central Asia for several purposes. 
Central Asia's economic and political modernization to which the United States hopes to keep partners together to maintain security in Central Asia and linking of local people and society. The purpose of the US is to restore the economic situation in Afghanistan as the center, building and the surrounding area and South Asia trade networks, improve infrastructure, the legal system, attract investment, and achieve transformation and upgrading of economic success, achieve a national smooth transition of economic sustainable development and social and consolidate it up to ten years. To improve America's position in the minds of the people of the region, to enhance the prestige, so that it can better establish long-term dominance.

Furthermore, Weaken of Russia in the Central Asian region and China in the Southeast Asian potential force. Finally, to strengthen the comprehensive national strength, enhance the international status, expanded in the United States in Southeast Asia and even the whole the influence of the Asia Europe region, "the New Silk Road" strategy is more like a foreign policy vision for Central Asia and South Asia (Chen and Liang, 2017).

President Xi Jinping met President Vladimir Putin in Moscow in May 2015 and signed numerous bilateral cooperation agreements. Out of the meeting, the most widely reported deal was the US $\$ 400$ billion gas agreement for 30 years, accords on transport infrastructure were also inked. China's NDRC, the Russian Ministry of Transport, Chinese Railways, and Russian Railways signed an agreement on cooperation and financing for a high-speed railway between Moscow and Kazan. Concerning the trilateral agreement of a so-called Northern Rail Corridor from Kuragino, Russia past a coking coal project in Ovoot, Mongolia to the port of Tianjin in China.

At a joint press conference with President Xi, Putin remarked that we think that the Eurasian integration project and the Silk Road Economic Belt project complement each other very harmoniously. So far, significant construction headway has been made on two projects in Russia under the BRI umbrella such as the high-speed Moscow-Kazan railway; and the Yamal liquefied natural gas (LNG) along the Northern Sea Route in the Arctic. The Moscow-Kazan railway of 770 $\mathrm{km}$ will link the Russian seat of government with Tatarstan's capital, which is the country's eighth-largest city. A part of this link could be of a longer highspeed rail system that connects Beijing to Berlin via Russia. The 400 billion roubles (US\$6.1 billion) have been sunk by the China Railway Group into the highspeed rail's construction, which will reduce travel time from 14 to 3.5 hours.

In building high-speed rail carriages, the Russian and Chinese have agreed to cooperate in Russia for the route with Chinese expertise. The early years of railway construction in 19th-century Russia are recalled by the Moscow-Kazan project when although the government built and owned some railway lines, a great deal was by the owner of foreign concessionaires and private companies. While China's involvement is notable given the Kremlin's mobilization of extremist nationalist rhetoric at certain times in support of its own goals. The highest-profile project in Russia is the Moscow-Kazan line involving Chinese capital and know-how, and future bilateral cooperation on Russian railroads may hinge on its success.

In constructing Arctic infrastructure, the Russians have a great deal, which the 
Soviets built with a combination of polar ingenuity and forced labor. Such projects are much harder to justify in a market economy given the high costs incurred by remote construction sites, challenging environmental conditions, and lack of local labor. The Arctic in Russia is centered on hydrocarbons, but with sanctions barring this sector from Western investment, Chinese capital may prove crucial in putting Russia's advanced northern knowledge to work so that to develop its Arctic and offshore oil and gas fields. More than finding new markets for Chinese products, BRI is also about connecting China with new resource frontiers like the Yamal Peninsula, which holds $22 \%$ of global proven gas reserves.

In Russian transportation infrastructure, China's investment ultimately may be about accessing new resources rather than accessing markets in Western Europe. On recent advances in bilateral energy cooperation, the BRI builds from the China Development Bank's US\$25 billion loans to Rosneft and Transneft to build the Eastern Siberia-Pacific pipeline in turn for 15 million tonnes of oil annually for 20 years, to the May 2014 US\$400 billion gas deal. China's first investment in Russia's oil and gas sector the Yamal LNG may signal a shift away from these previous agreements, which were made more with the Chinese view of Russia as the only energy supplier rather than as a destination for energy investments. It is for this reason, China's investment in Yamal more resembles its investments in Central Asia's oil and gas than its previous dealings in Russian energy (Berke, 2015).

In Russia's long-term interest to use Transsib primarily for other purposes, namely exporting raw materials such as coal, oil, oil products, wood and pulp, metals to Asia-Pacific markets and ensuring smooth logistics in the Russian Far East. Promoting the trans-Kazakhstan route in the interest of Russia which also traverses several thousand kilometers of Russian soil, thus bringing adequate revenues. The maritime transportation for all these routes is the real competitor, which is still responsible for 98.5-99 percent of China-Western Europe traffic. The potential positive implications of the BRI had been appreciated by the Russians early on. The Eurasian continental cooperation one of the advantages of which is the opportunity it presents to increase transport capacity.

The work in this area will generate several positive spillover effects as the trans-Eurasian links are being realized, such as more efficient use of transport capacity in transit countries. This type of cooperation leads to much better internal connectivity between inner-Eurasian regions, Central Asia, Siberia, the Urals, and the Caucasus. The Central Asian countries for Russia, their involvement in the BRI are also significant since it may open new regional development opportunities, boost individual regions' investment appeal, energize interregional cooperation, and speed up economic growth (Joshi, 2010).

The world's greatest economic construction and development project ever is being undertaken by China. In the economic map of the world, the New Silk Road project is a revolutionary change. In a battle between east and west for dominance in Eurasia, it is being viewed as the first shot. A modern transit, trade, and economic corridor as the resurrection of the ancient Silk Road is the ambitious vision that runs from Shanghai to Berlin. China, Mongolia, Russia, Belarus, Poland, and Germany, extending the road will traverse more than 8,000 miles, creating an economic zone that extends over one-third the circumference of the earth (Nate, 2014). 
To take a major role as bank charter members and partners in the project, China invited the international community. Additional funding is being expected through contributions from the members, including the World Bank, investments from private and public companies, and local governments. To become charter bank members 58 countries have signed, including most of Western Europe, along with many Silk Road and Asian countries. There are 12 NATO countries Netherlands, UK, Germany, Italy, France, Luxembourg, Iceland, Portugal, Denmark, Spain, Poland, and Norway, besides the US military allies in Asia S. Korea, Australia, and New Zealand.

The prime importance for India is the security and stability of Central Asia, which it considers part of its extended neighborhood. The stability of Afghanistan is also a concern for India. The ever-increasing Indian demand for energy which the energy-rich Central Asian countries can address, while improved transportation networks could provide a boost to continental trade across the region, benefiting India. Integrating South and Central Asia would result in vast economic benefits to all the stakeholders involved, leading to a positive outcome for stability and security in the region.

The period from 2000 to 2008 experienced a five-fold increase in intraregional trade between Central Asian countries, and the value of intraregional trade in food products, minerals, and textiles has since doubled. An important step in this process is expanding cooperation and regional energy trade (China-un. $\mathrm{ch}, 2021)$. Other regional energy projects that are currently under development complements CASA-1000. The TUTAP is being included would link the power grids of Turkmenistan, Uzbekistan, and Tajikistan with those of Afghanistan and Pakistan, and TAPI, a proposed natural gas line from Turkmenistan and would run through Afghanistan into Pakistan and then to India (Global Transmission Report, 2019).

\section{CONCLUSION}

The early 1990s saw a European request for a New Silk Road that would connect Europe with Central Asia via the International Transport Corridor Europe Caucasus Asia (TRACECA). China has recently disclosed particulars of the latest version of its land and maritime versions. The land versions begin at Xian in China and end at Venice, traversing Central Asia, Iran, and West Asia, Eastern Europe, and Germany, and the Netherlands. At Quanzhou in Fujian where the maritime Silk Road begins and ends at Venice, where it converges with the land route.

The US also got involved in the late 1990s first to bolster its influence in Central Asia, evident in the Silk Road Strategy Act of 1999, which could not make its presence. However, the US made her efforts to get India involved, for instance with the Turkmenistan, Afghanistan, Pakistan, and India TAPI pipeline projects. During visits to Central Asia and India in 2011, US President Clinton spoke in support of the Silk Road, while making India one of the pivots of the maritime silk route.

It is for India, that there are visions that will also benefit from rebalancing the Chinese in the maritime silk route, as it is the most important stakeholder in the 
New Silk Road. India must also make serious efforts to strengthen its associations with South East Asian countries and for this, it must also develop stronger ties with neighbors. India will also need to work towards a manageable relationship with SAARC countries, which would not only facilitate pipeline projects like TAPI but also enable access to Afghanistan and Central Asia.

Europe is still struggling with the aftermath of the global recession, along with China's growth slowdown, nowhere else could a project that promises so much opportunity be found. It is for the world at large, its decisions about the Road are nothing less than momentous. A new renaissance in discovery thought, invention, commerce, industry, and culture the potential of which is held by the massive project that could well rival the original Silk Road. The geopolitical conflicts over the project could lead to a new cold war between East and West for dominance in Eurasia as it is becoming clearer every day.

The economies of Central and South Asia are being connected through Afghanistan with the US-backed New Silk Road to promote prosperity and stability across the region. Building a regional energy market especially is the focus of this initiative, facilitating trade and transport, easing customs and border procedures, and promoting people-to-people ties, especially among businesspersons and entrepreneurs.

Similar to the natural resources of landlocked Central Asia, the lithium deposits in Afghanistan discovered recently the fate of which is to be destined in the same direction, controlled by the East and tapped by the West. Already channeled directly to China are the Kazakh oil, Turkmen natural gas, Mongolian iron ore, Siberian timber, and Afghan copper through a newly built East-bound network that is fueling the rapid development of the world's largest population. Across Central Asia, the building of railways, roads, and pipelines by China creates an opportunity for the West and the region itself.

In the long-term, the need for a strategy of such a far-reaching initiative, the New Silk Road has the potential to be one of the defining economic and political constructs of the initial decades of the 21 st Century, driving development, integrating and promoting trade, and providing stability across the world's largest landmass and beyond as well as cementing China's position as a regional and global superpower. In the scope of the New Silk Road, countries will need to formulate a response to China's moves, based on both their strategy and their views, its risks and benefits involved, and the rate of success.

A two-way street of mutually beneficial exchange for which the Silk Road has always remained. In more than a century no benefits have been delivered by the Durand Line. The oil-fueled Silk Road could do so soon. The United States for which it is important to engage with China on OBOR, but if it is to be effective, Washington needs to be conscious that Beijing still perceives the activities in the area as an effort to contain China. In Central Asia, the initiatives of Washington are frequently conceived with little consideration given to the Sino-U.S. ties. In Beijing, bilateral relationships are perceived as part of a broader U.S. aims of a strategy at hindering China's economic and military rise.

China has an interest in building stronger relations with its neighbors. Beijing's current discussion could have an immensely positive impact on some underde- 


\section{A JOURNEY FROM HISTORICAL TO MODERN ERA}

veloped economies. At the same time, Beijing should resist the impulse to dismiss U.S. actions as an attempt to subvert Chinese influence. In implementing many of its Silk Road proposals Beijing will face challenges, but a number of those challenges can be mitigated through early transparency and engagement. Similarly, the U.S. government's experiences over the past two decades make it a potentially productive partner in areas where the two countries' interests align.

The United States 'New Silk Road' strategic plan needs to cooperate and complementary to the Chinese one to reach win-win results. On the other hand, now in the United States strategic center has geared from the West to the East, under the background of countering terrorism, the Chinese western regional security problem becomes particularly severe. The United States implement the 'New Silk Road' plan in the south area of Asia, will affect the stability of China's western regional situation, economic and cultural development. And the government of the United States also understands China's influence in East Asia and the Middle East; reduces the funds invested in the South Asia region. Thus, seeking China's economic support and cooperation is essential. 


\section{REFERENCES}

Advantour.com (2021a). Turkmenistan on the Silk Road. Retrieved from http:// www.advantour.com/silkroad/turkmenistan.htm. Accessed: 01.05.2021.

Advantour.com (2021b). Tajikistan on the Silk Road. Retrieved from https:// www.advantour.com/silkroad/tajikistan.htm. Accessed: 01.05.2021.

Advantour.com (2021c). Kyrgyzstan and the Silk Road. Retrieved from https:// www.advantour.com/silkroad/kyrgyzstan.htm. Accessed: 01.05.2021.

Alf, Henryk (2016). "Flowing goods, hardening borders? China's commercial expansion into Kyrgyzstan reexamined". Eurasian Geography and Economics 57(3): 433-456.

Arpacik, Cihat and Yeni Safak (2015). Turkey, Syrian Turkmen team up to form United Turkmen Army. Retrieved from http://www.yenisafak.com/en/news/ turkey-syrian-turkmen-team-up-to-form-united-turkmen-army-2207584. Accessed: 05.12.2015.

Arzu, Turgut (2016). Greater Central Asia at the junction of New Silk Road. Institute of Social and Political Research.

Bai, Shouyi (1980). Outline History of China. Shanghai.

Baipakov, Karl M. and Dmitriy A. Voyakin (2010). "Sogdijcy srednevekovogo Kaalyka// Promyšlennost' Kazahstana [Sogdians of medieval Kayalyk]. Almaty 3(60): 94-98.

Bentley, Jerry (1993). Old World Encounters Cross-Cultural Contacts and Exchanges in Pre-Modern Times. Oxford University Press.

Berke, Robert (2015). China's new silk road could change global economics forever. Retrieved from https://www.businessinsider.com/chinas-new-silk-roadcould-change-global-economics-forever-2015-5. Accessed: 21.05.2015.

Bitabarova, Assel G. (2018). "Unpacking Sino-Central Asian engagement along the New Silk Road: a case study of Kazakhstan". Journal of Contemporary East Asia Studies 7(2): 149-173.

Boulnois, Luce (2005). Silk Road: Monks, Warriors and Merchants. Hong Kong: Odyssey Books.

Chen, Jian and Liang Qianying (2017). "Strategic implementation of the "New Silk Road" Between China and the U.S.". Atlantis Press Volume: Proceedings of the 2017 International Conference on Education, Economics and Management Research (ICEEMR 2017).

China-un.ch (2021). The Belt and Road initiative progress, contributions and prospects. Retrieved from http://www.china-un.ch/eng/zywjyjh/t1675564.htm. Accessed: 08.05.2019.

Choganov, Kerven (2021). Turkmenistan's strategic corridors. Retrieved from https://www.oboreurope.com/en/turkmenistan-strategic-corridors/. Accessed: 01.05.2021.

Chou, Mark and Octavia Bryant (2015). "Will China promote autocracy along 
its New Silk Road?". Carnegie Council for Ethics and International Affairs.

Cis-legislation.com (2019). About Turkmenistan. Retrieved from https://cis-leg-

islation.com/cis/turkmenistan/index.html.2019. Accessed: 08.05.2019.

Cooley, Alexander (2014). Great Games, Local Rules. Oxford University Press.

Czerewacz-Filipowicz, Katarzyna (2019). "The Eurasian Economic Union as an Element of the Belt and Road Initiative". Comparative Economic Research. Central and Eastern Europe 22(2): 23-37.

Dadabaev, Timur and Nigora Djalilova (2020). "Connectivity, energy, and transportation in Uzbekistan's strategy vis-à-vis Russia, China, South Korea, and Japan". Asia Europe Journal No. 19, pp. 105-127.

Europe-China.kz (2020). Western Europe-Western China Transit Corridor. Retrieved from http://europe-china.kz/en. Accessed: 28.05.2020.

Fedorenko, Vladimir (2013). The New Silk Road initiatives in Central Asia. Rethink Institute, Washington D.C.

Finn, Tom (2015). Turkey to set up Qatar military base to face 'common enemies'. Retrieved from http://www.reuters.com/article/us-qatar-turkey-military-idUSKBN0TZ17V20151216. Accessed: 16.12.2015.

Frolovskiy, Dmitriy (2016). Amid Russian Downturn, Kyrgyzstan Turns to China. Retrieved from http://thediplomat.com/2016/07/amidrussian-downturn-kyrgyzstan-turns-to-china/. Accessed: 01.07.2016.

Ghani, Abdullo R. (2021). Tajikistan and the "Economic belt" of the Great Silk Road. Retrieved from https://cabar.asia/en/. Accessed: 01.05.2021.

Ghiyasi, Richard and Jiayi Zhou (2017). The Silk Road economic belt: Considering security implications and EU-China cooperation prospects. SIPRI Stockholm International Peace Research Institute.

Global Transmission Report (2019). Afghanistan: Embarks on growth backed by international support. Retrieved from www.globaltransmission.info/archive. php?id=36687. Accessed: 08.05.2019.

Greater Pacific (2015). China's New Silk Road: Tactics, Overstretch or Grand Strategy?. Retrieved from https://www.greaterpacificcapital.com/thought-leadership/chinas-new-silk-road-tactics-overstretch-or-grand-strategy. Accessed: 29.12.2015.

Guluzian, Christine R. (2017). “Making Inroads: China’s New Silk Road Initiative". Cato Journal 37(1): 135-147.

Hurriyetdailynews.com (2015). Turkish military to have a base in Iraq's Mosul. Retrieved from http://www.hurriyetdailynews.com/turkish-military-to-havea-base-in-iraqs-mosul.aspx?pageID $=238 \& n I D=92113 \&$ NewsCatID $=352$. Accessed: 05.12.2015.

Ishjamts, Nyambuugiin (2021). Nomads in Eastern Central Asia, Early Mongolia. Retrieved from https://zh.unesco.org/silkroad/node/331. Accessed: 01.06.2021. 
Jochec, Marek and Jenny J. Kyzy (2015). "China’s BRI Investments, Risks, and Opportunities in Kazakhstan and Kyrgyzstan". The Silk Road Economic Belt's Impacts on Central Asia, p. 70, (Ed. Marlene Laruelle).

Joshi, Nirmala (Ed.) (2010). Reconnecting India and Central Asia. Emerging Security and Economic Dimensions, Central Asia-Caucasus Institute and Silk Road Studies Programme.

Khamidova, Nargiza (2017). The reincarnation of the Silk Road and the influence of transportation to economic development: The case of Central Asia and Uzbekistan. Helsinki Metropolia University of Applied Sciences Business Administration International Business and Logistics.

Konovalov, Procopius B. (1976). Khunnu v Zabaykal'yep (Hunnu in Transbaikalia). Ulan-Ude: Buryat book publishing house

Linn, Johannes (2012). Central Asian regional integration and cooperation: Reality or mirage? The Economic of the Post-Soviet and Eurasian Integration, EDB Eurasian Integration Yearbook.

Lisbonne de Vergeron, Karine (2018). "The New Silk Road: European perceptions and perspectives”. International Studies 55(4): 339-349.

Lobyrev, Vitaly, Andrey Tikhomirov, Taras Tsukarev and Evgeny Vinokurov (2018). Belt and Road Transport Corridors: Barriers and Investments. Eurasian Development Bank Centre for Integration Studies', Report No. 50, pp. 8-11.

Mark, Joshua J. (2014). Silk Road definition, Ancient History Encyclopaedia. Retrieved from https://www.worldhistory.org/Silk_Road/. Accessed: 01.05.2018.

Mehendale, Sanjyot (1996). "Begram: Along ancient Central Asian and Indian trade routes". Cahiers d'Asie Centrale 1(2): 47-64.

Mogilevskii, Roman (2019). Kyrgyzstan and the Belt and Road Initiative. University of Central Asia - Institute of Public Policy and Administration (IPPA) Working Paper No. 50.

Nate, Bills (2014). Powering a New Silk Road: Helping connect supply with demand in south and Central Asia. Frontlines, USAID.

Okladnikov, Alexei P. (1955). Neolit i bronzovyy vek Pribaykal'ya (Neolithic and Bronze Age of the Baikal region). Moscow: Leningrad

Peters, Michael A. (2019). "The ancient Silk Road and the birth of merchant capitalism". Educational Philosophy and Theory.

Peyrouse, Sebastien (2012). "The Kazakh neopatrimonial regime: Balancing uncertainties among the 'Family,' oligarchs and technocrats". Demokratizatsiya: The Journal of Post-Soviet Democratization 20(4): 365.

Reiser, Martin and Dennis DeTray (2007). "Uzbekistan: On the Slow Lane of the New Silk Roads? In The New Silk Roads". Washington, D.C: Central Asia-Caucasus Institute and Silk Road Studies Program, pp. 193-235.

Reynolds, Sam (2018). For Tajikistan, the Belt and Road Is Paved with Good Intentions. Retrieved from https://nationalinterest.org/feature/tajikistan-belt-androad-paved-good-intentions-29607. Accessed: 23.08.2018. 
Selmier II, W. Travis (2019). Kazakhstan as logistics linchpin in the Belt and Road initiative. Project: Belt and Road Initiative and the Silk Road, Indian University.

Standish, Reid (2015). The United States' Silk Road to nowhere, foreign policy. Retrieved from https://foreignpolicy.com/2014/09/29/the-united-states-silkroad-to-nowhere-2/. Accessed: 05.11.2015.

Starr, Frederick S., Svante Cornell and Nicklas Norling (2015). The EU, Central Asia, and the development of continental transport and trade. Silk Road Paper series. The Institute for Security and Development Policy, Stockholm.

The Economic Times (2015). Silk Road projects could benefit India: CII official. Retrieved from https://economictimes.indiatimes.com/news/economy/infrastructure/silk-road-projects-could-benefit-india-cii-official/articleshow/46726238.cms. Accessed: 29.05.2015

Turchin, Peter, Jonathan M. Adams and Thomas D. Hall (2006). "East-West orientation of historical empires". Journal of world-systems research 12 (2): 219-229.

U.S. Embassy in Tajikistan (2015). Secretary Kerry travels to Vienna, Bishkek, Samarkand, Astanta, Dushanbe and Ashgabat. Retrieved from https://tj.usembassy.gov/secretary-kerry-travels-vienna-bishkek-samarkand-astanta-dushanbe-ashgabat/. Accessed: 27.10.2015.

Umesao, Tadao and Toh Sugimara (Eds.) (1992). Significance of Silk Road in the History of Human Civilization. Osaka: National Museum of Ethnology.

UNESCO (2021a). About the Silk Road. Retrieved from https://en.unesco.org/ silkroad/about-silk-roads. Accessed: 01.06.2021.

UNESCO (2021b). Tajikistan. Retrieved from https://en.unesco.org/silkroad/ countries-alongside-silk-road-routes/tajikistan. Accessed: 01.06.2021.

Vinokurov, Evgeny (2019). The Belt and Road Initiative: A Russian Perspective. In: Harinder S. Kohli, Johannes F. Linn and Leo M. Zucker (Eds.) China's Belt and Road Initiative: Potential Transformation of Central Asia and the South Caucasus.

Voyakin, Dmitriy A. and Aleksandr V. Pachkalov (2010). Monetnye nahodki na gorodische Dzhan-kala// Istoriko-kul'turnoe nasledie aralo-kaspijskogo regiona. Materialy II mezhdunarodnoj nauchno-practičeskoj konferencii [Coin findings of the settlement of Dzhan-kala// Historical and cultural heritage of Aral and Caspian regions. Materials of second international scientifi $\mathrm{c}$ and practical conference], pp. 55-63.

Wang, Helen H. (2016). China's Triple Wins: The New Silk Road. Retrieved from https://www.forbes.com/sites/helenwang/2016/01/15/chinas-triple-winsthe-new-silk-roads/?sh=2f2c5fd06f7f. Accessed: 05.12.2016.

Wang, Ye (2017). Full text of President Xi Jinping speech at the opening of Belt and Road Forum. Retrieved from http://www.xinhuanet.com//english/2017-05/14/c_136282982.htm. Accessed: 14.05.2017.

Warren, Rebecca (2017). China's Belt and Road Initiative: a Eurasian Game. 
Defence-in-Depth, Research from the Defence Studies Department, King's College London.

Weitz, Richard (2015). US New Silk Road Initiative Needs Urgent Renewal. The Central Asia-Caucasus Analyst, March 2015.

Wijeratne, David, Mark Rathbone and Frank Lyn (2017). Repaving the ancient Silk Routes. PwC Growth Markets Centre - Realising opportunities along the Belt and Road.

Wilder, Charly (2020). 12 days on the most storied highway of them all: The Silk Road. Retrieved from https://www.nytimes.com/2020/03/09/travel/ silk-road-uzbekistan-tajikistan-kyrgyzstan.html. Accessed: 09.03.2020.

Yildiz, Firat (2007). Turkmenistan. The New Silk Road: Transport and Trade in Greater Central Asia, Central Asia - Turkmenistan, Caucasus Institute and Silk Road Studies Programme, p. 143, (Ed. Frederick Starr).

Zhumabayeva, Aigerim, Bauyrzhan Bozhbanbayev, Aizhan Turgenbayeva, Arman Aubakir and Kairat Zhanabayev (2018). "The role of the environment: Silk Road in the history of Turkic people". Opción No. 85: 522-550.

Zimmerman, Thomas (2015). The New Silk Road: China, the U.S., and the Future of Central Asia. New York University, Centre for International Cooperation. 